\title{
Eccrine Porocarcinoma, A Rare Aggressive Malignant Adnexal Tumor of the Skin: A Case Report
}

\author{
Nishith Vaddeboina ${ }^{1 *}$, Suresh AVS ${ }^{1}$, Dattatreya PS ${ }^{1}$, Rakesh Sharma ${ }^{2}$ and Mohana Vamsy ${ }^{3}$ \\ ${ }^{1}$ Department of Medical oncology, Omega hospitals, India \\ ${ }^{2}$ Department of clinical statistics, Omega hospitals, India \\ ${ }^{3}$ Senior consultant, Department of Surgical oncology, Omega Hospitals, India
}

Submission: May 31,2021; Published: June 21, 2021

*Corresponding author: Nishith Vaddeboina, Department of Medical oncology, Omega hospitals, MLA colony, Banjara hills, Hyderabad, Telangana, India India

\begin{abstract}
We present a case of 71-year-old male who presented with a painless nodular growth on the lateral aspect of left thigh. MRI was suggestive of irregular exophytic lesion in the left gluteal region with enlarged left inguinal nodes. Biopsy suggested malignant adnexal tumor-porocarcinoma. Patient underwent wide local excision followed by adjuvant chemotherapy and radiation. In spite of the aggressive management, patient had a local disease recurrence within 3 months.
\end{abstract}

Keywords: Porocarcinoma; Malignant adnexal skin tumor; Aggressive skin tumor

Abbreviations: MRI: Magnetic Resonance Imaging, EPC: Eccrine Porocarcinoma

\section{Introduction}

Eccrine porocarcinoma (EPC) is a rare tumor which was initially described by Pinkus and Mehregan as epidermotropic eccrine carcinoma [1,2]. It develops from the intraepidermal ductal portion of the eccrine sweat gland [3]. $20 \%$ of these tumors are considered to be aggressive and Metastasis occurred less frequently. Literature regarding the appropriate management of this tumor is lacking due to the rarity of the disease. We report a case of Porocarcinoma of Left thigh which recurred in 3months despite aggressive management with combined modality.

\section{Case Report}

A 71-year-old male patient presented with a $3 \mathrm{~cm}$ nodular painless growth on the lateral aspect of left thigh. Patient apparently noticed this painless swelling 2 years ago which gradually increased in size, without any associated symptoms. Patient noticed bleeding from the growth which was managed conservatively. Subsequently the patient underwent MRI which showed an irregular exophytic cutaneous altered signal intensity lesion in the left gluteal region laterally with mild adjacent subcutaneous edema with enlarged left inguinal nodes. Biopsy was performed which was suggestive of Malignant epithelial neoplasm, morphology suggestive of malignant adnexal tumorporocarcinoma. Staging workup was done with PET CT scan which showed $48 X 25 \times 50 \mathrm{~mm}$ metabolically active heterogeneously enhancing exophytic cutaneous lesion in the lateral aspect of the left gluteal region with mildly avid enlarged left inguinal nodes.

Patient underwent Left Wide local excision and ilioinguinal block dissection. Histopathology showed malignant adnexal tumor with multiple left inguinal and left pelvic nodes positive for malignancy.

After discussing in the multidisciplinary tumor board, Patient was started on adjuvant chemotherapy with Mitomycin-C and 5FU for 6 cycles with EBRT of 60Gy in 30 fractions to the surgical bed. Patient tolerated treatment well with very little treatment related toxicity. PET-CT scan was performed 3 months after completion of the treatment and it was negative for active disease. Subsequent scan at 6 months showed a left inguinal nodal recurrence and patient was given radiation to the diseased node. 


\section{Cancer Therapy \& Oncology International Journal}

\section{Discussion}

Primary adenocarcinoma arising from the eccrine sweat glands is very rare, representing approximately $0.005 \%$ of epithelial cutaneous neoplasms [1]. It occurs in the elderly, usually after 60 years [4]. The predilection site is the lower extremities (55\%), followed by the head and scalp (20\%), upper limbs (12\%), and trunk and abdomen (10\%) [5]. The differential diagnosis with other malignant tumors of the skin is very complex, especially with seborrheic keratosis, Bowen tumor, multifocal basal cell carcinoma, lymphoma, achromic melanoma, pyogenic granuloma, wart, and nevus [6]. Metastasis occurs in about $20 \%$ of cases with a very poor outlook and high mortality. Most common site was lymph nodes, lung, retroperitoneum, and liver [7].

The main treatment for localized form is surgical excision with histologically clear margins [8]. Role of adjuvant chemotherapy and radiotherapy is not clearly defined for locally advanced porocarcinoma. Various chemotherapeutic agents like Docetaxel, 5FU, Mitomycin-c, Doxorubicin, Vincristine, cyclophosphamide is known to be effective but sufficient data is not available to standardize the treatment. Effectiveness of radiotherapy is unknown and the available data is controversial regarding its role in the management of porocarcinoma. Our patient underwent wide local excision with ilioinguinal dissection and in view of positive nodes, adjuvant chemotherapy and radiotherapy were administered following which patient showed complete response but subsequently the patient had regional nodal recurrence for which he was irradiated.

\section{Conclusion}

Eccrine porocarcinoma is a rare malignant adnexal tumor of skin which is diagnosed based on the morphological characteristics. Management is primarily surgical excision and if clinically nodes are detected, lymphadenectomy should be considered. Although data regarding adjuvant treatment is unknown, our patient was managed aggressively with adjuvant chemotherapy and radiotherapy as he was deemed as high risk for recurrence. In spite of this aggressive management, patients developed nodal recurrence within 6 months which suggests the aggressive nature of the disease.

\section{References}

1. Chang NC, Tsai KB (2009) Eccrine porocarcinoma of the auricle: a case report. Kaohsiung J Med Sci 25(7): 401-404.

2. Pinkus H, Mehregan AH (1963) Epidermotropic eccrine carcinoma. Arch Dermatol 88: 597-606.

3. Arbona E, Balm B (2010) Porome eccrine et porocarcinome. Annales de Dermatologie et de Vénéréologie 137(10): 660-662.

4. Cazeaua C, Lepreuxb S, Taieba A, Delaunaya M, Jouarya T, et al. (2008) Le porocarcinome eccrine: une tumeur annexielle cutanée maligne hautement aggressive. Ann Dermatol Venereol 135(10): 722-724.

5. Huet P, Dandurand M, Pignodel C, Guillot B (1996) Metastasizing eccrine porocarcinoma: report of a case and review of the literature. Journal of the American Academy of Dermatology 35(5 part 2): 860864.

6. Aaribi I, Mohtaram A, Ben Ameur El Youbi M, Kharmoum J, El Kabous M, et al. (2013) Successful management of metastatic eccrine porocarcinoma. Case Rep Oncol Med 2013: 282536.

7. Snow SN, Reizner GT (1992) Eccrine porocarcinoma of the face. Journal of the American Academy of Dermatology 27(2 pt 2): 306-311.

8. Pernia LR, Guzman-Stein G, Miller HL (1993) Surgical treatment of an aggressive metastasized eccrine poroma. Ann Plast Surg 30(3): 257-259.

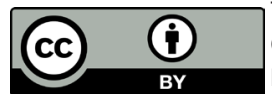

is work is licensed under Creative Commons Attribution 4.0 License DOI:10.19080/CTOIJ.2021.19.556004
Your next submission with Juniper Publishers will reach you the below assets

- Quality Editorial service

- Swift Peer Review

- Reprints availability

- E-prints Service

- Manuscript Podcast for convenient understanding

- Global attainment for your research

- Manuscript accessibility in different formats ( Pdf, E-pub, Full Text, Audio)

- Unceasing customer service

Track the below URL for one-step submission https://juniperpublishers.com/online-submission.php 